DOI

\title{
ВПЛИВ КЛІТИННОӦ ТЕРАПІЇ НА ДИНАМІКУ ПРОЦЕСІВ ЦИТОЛІЗУ В РАННІЙ І ПІЗНІЙ ПЕРІОД ПОЄДНАНОЇ КРАНІОСКЕЛЕТНОЇ ТРАВМИ, УСКЛАДНЕНОЇ КРОВОВТРАТОЮ
}

\section{ПВНЗ «Київський медичний університет УАНМ» МОЗ України}

РЕЗЮМЕ. В умовах краніоскелетної травми, ускладненої крововтратою, впродовж періоду ранніх і пізніх проявів травматичноїхвороби (3-25 діб) відмічається виражений синдромцитолізу, який супроводжується істотним збільшенням активності аспартат- і аланінамінотрансфераз сироватки крові впродовж 25 діб посттравматичного періоду. Застосування кріоконсервованих фетальних нервових клітин у цих експериментальних умовах супроводжується вираженим цитопротекторним ефектом, який найбільше виражений через 14 і 25 діб експерименту.

КЛЮчОВІ СлОВА: краніоскелетна травма, крововтрата, клітинна терапія, цитоліз.

Вступ. У сучасних умовах травматизм посідає перше місце у структурі смертності серед працездатного населення [10]. Незважаючи на значні успіхи у розумінні патогенезу тяжкої травми та лікуванні постраждалих, актуальною проблемою залишається розкриття нових патогенетичних механізмів травматичної хвороби та розробка на їх основі досконаліших технологій корекції.

Тяжким ускладненням травматичної хвороби $\epsilon$ розвиток поліорганної недостатності. В основі її патогенезу лежать патологічні зміни клітинних мембран з їх подальшою загибеллю шляхом некрозу чи апоптозу. Некротичні зміни завдяки виходу лізосомальних ферментів створюють несприятливий фон для одужання. Вони посилюють процеси запалення з розвитком системних реакцій організму [6].

Серед засобів системної корекції останнім часом увага дослідників зосереджується на терапії фетальними нервовими клітинами. Їх терапевтичний потенціал зумовлений ангіогенним, антиапоптотичним, антиоксидантним і мітогенним ефектами $[1,12]$. Існує припущення, що механізми відновлення зумовлені не диференціюванням клітин, а звільненням трофічних факторів, які стимулюють ендогенні механізми репарації, знижують клітинну загибель і стимулюють ангіо- і нейрогенез, що підтверджується експериментально [11]. Однак вплив клітинної терапії на процеси цитолізу в умовах тяжкої травми вивчений недостатньо, що вимагало спеціального дослідження.

Мета роботи: з'ясувати вплив клітинної терапії на динаміку процесів цитолізу в ранній і пізній періоди поєднаної краніоскелетної травми, ускладненої крововтратою.

Матеріал і методи дослідження. В експериментах використано 104 нелінійних білих щурисамці масою 180-200 г, яких утримували на стан- дартному раціоні віварію. Тварин поділили на три групи: контрольну і дві дослідні. У контрольну групу увійшли 8 інтактних тварин. В обох дослідних групах - по 48 тварин - під тіопентало-натрієвим наркозом (40 мг· $\mathrm{K}^{-1}$ маси тіла) моделювали закриту черепно-мозкову травму за методикою [7] у власній модифікації. Енергія удару становила 0,375 Дж, що відповідало травмі середнього ступеня тяжкості. Крім цього, спеціально розробленим пристроєм наносили однократний удар по кожному стегну, що викликало закритий перелом стегнових кісток. Додатково викликали кровотечу зі стегнової вени, яка супроводжувалася крововтратою в межах 20-22 \% об'єму циркулюючої крові.

Через 12 год після травмування в одній із дослідних груп тваринам внутрішньочеревно вводили суспензію кріоконсервованих фетальних нервових клітин щура в дозі $5 \times 10^{6}$ клітин на 100 г маси тварини [4]. Суспензію фетальних нервових клітин виготовляли в Інституті проблем кріобіології і кріомедицини НАН України (м. Харків) шляхом щадної механічної дисоціації фрагментів мозку ембріонів щурів 11-ти діб гестації і кріоконсервування на програмному заморожувачі УОП-6. Відігрівання зразків проводили на водяній бані при температурі $37^{\circ} \mathrm{C}$. Тваринам іншої дослідної групи внутрішньочеревно вводили еквівалентний об'єм фізіологічного розчину.

Тварин, які вижили, виводили з експерименту через 3, 7, 14 і 25 діб посттравматичного періоду. У сироватці крові піддослідних тварин, які вижили в ході експерименту, уніфікованим методом для аналізатора біохімічного Humalyzer 2000 з використанням наборів реактивів фірми Human (Німеччина) визначали активності аспартат- і аланінамінотрансфераз (АсАТ і АлАТ).

Під час роботи з лабораторними тваринами дотримувались міжнародних вимог щодо гуманного поводження з тваринами відповідно до 
Огляди літератури, оригінальні дослідження, погляд на проблему

правил «Європейської конвенції захисту хребетних тварин, яких використовують з експериментальною та іншою науковою метою» (European Convention, 1984); методичних рекомендацій ДФЦ МОЗ України про "Доклінічні дослідження лікарських засобів» (2001). Евтаназію щурів у всіх експериментах проводили шляхом тотального кровопускання з серця після попереднього тіопентало-натрієвого наркозу (60 мг·Кг $\Gamma^{-1}$ маси тіла тварини внутрішньочеревно).

Одержаний цифровий матеріал обробляли у відділі системних статистичних досліджень ДВН3 «Тернопільський державний медичний університет імені І. Я. Горбачевського МОЗ України» у програмному пакеті STATISTICA ("StatSoft Inc.», CША) з використанням непараметричного критерію Манна-Уїтні.

Результати й обговорення. При дослідженні активності АсАТ сироватки крові у тварин без корекції виявлено статистично вірогідне зростання показника вище контрольної величини у всі терміни дослідження (табл. 1). Так, через 3 доби показник був більшим на $52,2 \%(p<0,05)$, через 7 діб - на 33,0 \% ( $<<0,05)$, через 14 діб - на 45,1\% ( $p<0,05)$, через 25 діб - на 45,9\% ( $<<0,05)$. Аналіз його динаміки показав (рис. 1), що показник че- рез 3 доби досягав максимальної величини і залишався на практично такому ж рівні до 25 доби, за винятком 7 доби від початку експерименту, коли він знижувався і був статистично вірогідно меншим, порівняно з попереднім терміном дослідження, на $19,2 \%(p<0,05)$.

У тварин, яким проводили клітинну корекцію (табл. 1), активність у сироватці крові АсАТ перевищувала рівень контролю через 3, 7 і 14 діб від початку експерименту, відповідно, на 45,1, 23,5 і $20,2 \%(p<0,05)$. Через 25 діб показник знижувався й вірогідно від контролю не відрізнявся $(p>0,05)$. Аналіз динаміки досліджуваного показника виявив (рис. 1), що він через 3 доби після нанесення травми досягав максимальної величини і згодом знижувався. Через 7, 14 і 25 діб від початку експерименту показник був статистично вірогідно меншим, ніж через 3 доби (відповідно, на 21,6, 44,9 і $29,5 \%(p<0,05)$.

Порівняння дослідних груп між собою показало (табл. 1), що через 3 і 7 діб істотних відмінностей не спостерігалося ( $>>0,05)$, проте через 14 і 25 діб після нанесення травми активність АсАТ сироватки крові під впливом клітинної терапії виявилася істотно меншою, ніж у тварин без корекції (відповідно на 24,9 і 30,3\%, p<0,05).

Таблиця 1. Вплив клітинної терапії на динаміку активності АсАТ і АлАТ сироватки крові у відповідь на

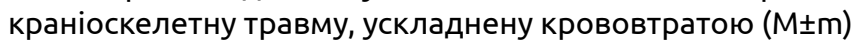

\begin{tabular}{|c|c|c|c|c|}
\hline $\begin{array}{c}\text { Умови } \\
\text { експерименту }\end{array}$ & 3 доба & 7 доба & 14 доба & 25 доба \\
\hline \multicolumn{5}{|c|}{$\begin{array}{c}\text { АсАТ } \\
\text { Контроль }=(184,7 \pm 7,1) \text { од } \cdot \pi^{-1}(n=8)\end{array}$} \\
\hline \multirow{2}{*}{ Без корекції } & $281,1 \pm 8,7^{*}$ & $245,6 \pm 8,2^{*}$ & $268,0 \pm 10,5^{*}$ & $269,5 \pm 12,6^{*}$ \\
\hline & $(n=6)$ & $(n=6)$ & $(n=5)$ & $(n=5)$ \\
\hline \multirow{2}{*}{ Клітинна терапія } & $267,9 \pm 9,5^{*}$ & $228,1 \pm 9,0^{*}$ & $222,1 \pm 10,6^{*}$ & $213,5 \pm 14,2$ \\
\hline & $(n=7)$ & $(n=8)$ & $(n=7)$ & $(n=7)$ \\
\hline$P$ & $>0,05$ & $>0,05$ & $<0,05$ & $<0,05$ \\
\hline \multicolumn{5}{|c|}{$\begin{array}{c}\text { АлАТ } \\
\text { Контроль }=(103,1 \pm 2,5) \text { од } \cdot \pi^{-1}(n=8)\end{array}$} \\
\hline \multirow{2}{*}{ Без корекції } & $168,3 \pm 6,5^{*}$ & $133,7 \pm 6,9^{*}$ & $156,5 \pm 5,3^{*}$ & $125,0 \pm 5,8^{*}$ \\
\hline & $(n=6)$ & $(n=6)$ & $(n=5)$ & $(n=5)$ \\
\hline \multirow{2}{*}{ Клітинна терапія } & $175,0 \pm 7,5^{*}$ & $125,7 \pm 3,4^{*}$ & $136,5 \pm 7,5^{*}$ & $106,0 \pm 3,6$ \\
\hline & $(n=7)$ & $(n=8)$ & $(n=7)$ & $(n=7)$ \\
\hline$P$ & $>0,05$ & $>0,05$ & $<0,05$ & $<0,05$ \\
\hline
\end{tabular}

Примітки: 1. * - відмінності стосовно контрольної групи статистично вірогідні $(p<0,05)$; 2. p - вірогідність відмінностей між групами тварин, які отримували клітинну терапію, та тварин без корекції. 
Огляди літератури, оригінальні дослідження, погляд на проблему

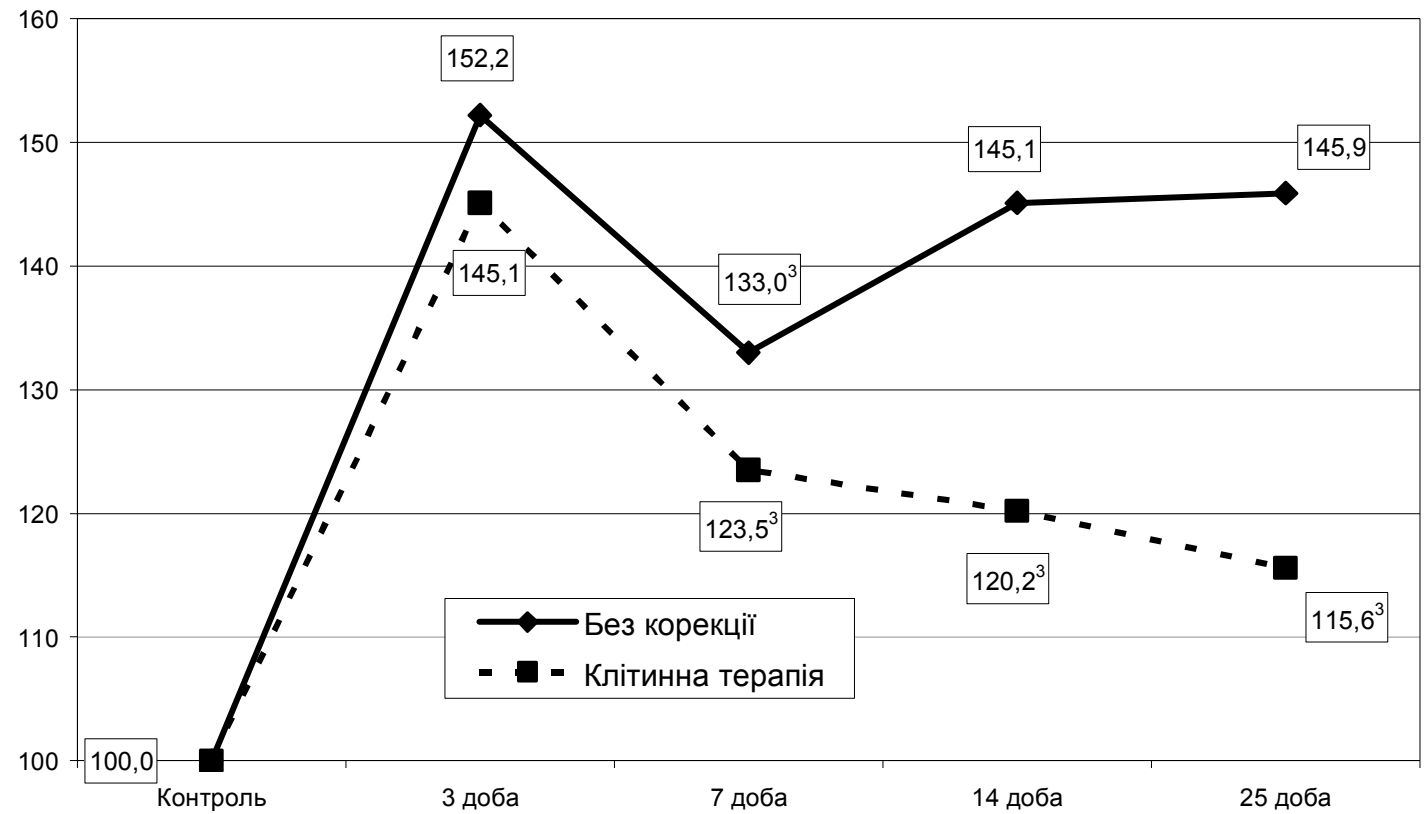

Рис. 1. Динаміка активності АсАТ сироватки крові (у відсотках від рівня контролю) у тварин з краніоскелетною травмою, ускладненою кровотечею, під впливом клітинної терапії. Тут і на рисунку 2: 3, 7, 14 - відмінності стосовно 3,7 і 14 діб статистично вірогідні $(p<0,05)$.

Активність АлАТ у тварин без проведеної клітинної терапії також значно перевищувала контрольну величину в усі терміни дослідження і мала хвилеподібний характер (табл. 1).

Через 3 доби після нанесення травми, ускладненої кровотечею, активність АлАТ перевищувала контроль на 63,2 \% (p<0,05), через сім ді6 - на 29,7 \% $(p<0,05)$, через 14 діб на 51,8\% $(p<0,05)$, через 25 на $21,1 \%(p<0,05)$. У динаміці показника (рис. 2) від- мічено, що через 7 діб від початку експерименту активність АлАТ сироватки крові виявилася статистично вірогідно меншою на $33,5 \%(p<0,05)$, порівняно з попереднім терміном дослідження. Через 14 діб, порівняно з попереднім терміном дослідження, вона зростала на 22,1 \% ( $<<0,05)$. Через 25 ді6 показник повторно знижувався і ставав меншим, порівняно з величинами, отриманими через 3 доби (на 42,1\%, р<0,05) і 14 діб (на 30,7 \%, p<0,05).

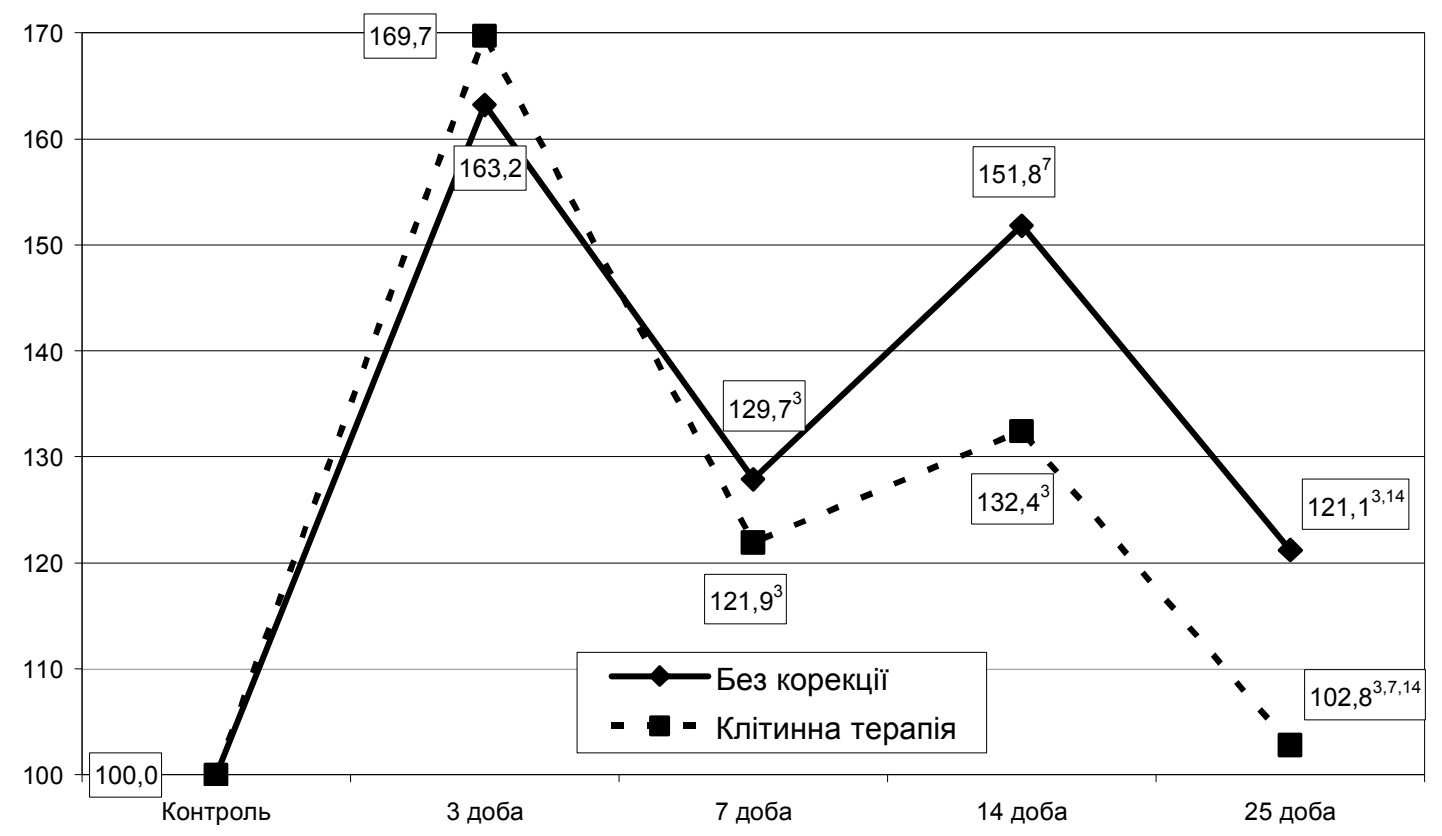

Рис. 2. Динаміка активності АлАТ сироватки крові (у відсотках від рівня контролю) у тварин з краніоскелетною травмою, ускладненою кровотечею, під впливом клітинної терапії. 
Огляди літератури, оригінальні дослідження, погляд на проблему

При проведенні клітинної терапії активність АлАТ сироватки крові була вищою від норми через 3, 7 і 14 діб після нанесення травми (відповідно на $69,7,21,9$ і $32,4 \%$ ( $<<0,05)$. Виявилося, що порівняно з результатами, які отримано через 3 доби (рис. 2), через 7 діб показник був статистично вірогідно меншим на $47,8 \%(p<0,05)$, через 14 діб - на 37,3 \% ( $<<0,05)$. Через 25 діб активність АлАТ не відрізнялася від контрольної величини і була меншою, порівняно з даними, отриманими через три доби після початку експерименту, на $66,9 \%(p<0,05)$, через 7 діб - на 19,1\% ( $<<0,05)$, через 14 діб - на 29,6\% ( $<<0,05)$.

Порівняння дослідних груп між собою (табл. 1) не виявило істотних відмінностей через 3 і 7 діб після нанесення травми $(p>0,05)$. Проте через $14 \mathrm{i}$ 25 ді6 посттравматичного періоду при проведенні клітинної терапії показник був меншим, порівняно із тваринами без корекції (відповідно, на 19,4 i $18,3 \%, p<0,05)$.

Отримані результати свідчать про те, що експериментальна краніоскелетна травма, ускладнена крововтратою, супроводжується явищами цитолізу. Активність АсАТ і АлАТ сироватки крові істотно перевищує рівень контролю в усі терміни спостереження, що узгоджується із даними інших авторів про значну виразність цитолітичного синдрому на тлі як черепно-мозкової [7], так і скелетної травм [8]. Характерною рисою динаміки активності АСАТ сироватки крові у тварин із модельованою травмою $\epsilon$ досягнення нею статистично вірогідно вищого рівня, порівняно з контрольною групою, вже через 3 доби, він залишався стабільно високим до закінчення експерименту із періодом тимчасового зниження через 7 діб. Що стосується активності АлАТ сироватки крові, то у всі терміни посттравматичного періоду величина показника теж перевищувала рівень контролю, проте ії динаміка була хвилеподібною із першим підйомом через 3 доби, зниженням - через 7 діб, повторним підйомом через 14 діб і зниженням через 25 діб.

Отримані результати свідчать про те, що у патогенезі періоду ранніх і пізніх проявів травматичної хвороби на тлі краніоскелетної травми, ускладненої крововтратою, виникає системна мембранопатія, яка стосується як ендоплазматичних, так і цитоплазматичних мембран, що особливо виражено через 3 доби посттравматичного періоду. Можна припустити, що вагомим чинником у розвитку порушень на тлі краніоскелетної травми $\epsilon$ гіпоксія, зумовлена втратою крові. В цих умовах стимулюється утворення активних форм кисню, пероксидне окиснення ліпідів [7], які, очевидно, відграють основну роль у збільшенні проникності клітинних мембран і $є$ причиною системних проявів тяжкої травми.

Застосування клітинної терапії зумовлювало виражений цитопротекторний вплив, який був найбільше вираженим у період пізніх проявів травматичної хвороби - через 14 і 25 діб посттравматичного періоду. Враховуючи, що саме в цей період травматичної хвороби виникають виражені порушення функції життєво важливих органів і систем, створюються основні передумови розвитку поліорганної недостатності, можна припустити, що терапія кріоконсервованими фетальними нервовими клітинами здатна долати системні відхилення, які при цьому виникають.

Наші попередні дослідження показали, що внаслідок клітинної терапії в умовах краніоскелетної травми відмічається зниження інтенсивності процесів ліпідної пероксидації [2], менше виснажується антиоксидантний захист [3]. Існує припущення, що в основі цього ефекту лежить безпосередній антиоксидантний вплив клітинної терапії [9]. Крім цього, фетальним клітинам характерне активне виділення низки біологічно активних речовин, у тому числі факторів росту [5], здатних мобілізувати функціональні резерви організму. Можна припустити, що завдяки клітинній терапії в умовах травми залучаються механізми захисту різного рівня організації живої тканини, що вимагає подальшого вивчення.

Висновки. 1. В умовах краніоскелетної травми, ускладненої крововтратою, протягом періоду ранніх і пізніх проявів травматичної хвороби відмічається виражений синдром цитолізу, який супроводжується істотним збільшенням активності АсАт і АлАТ сироватки крові впродовж 25 діб посттравматичного періоду.

2. Застосування фетальних нервових клітин в умовах краніоскелетної травми, ускладненої крововтратою, супроводжується вираженим цитопротекторним ефектом, який найбільше виражений через 14 і 25 діб експерименту.

Перспективи подальших досліджень. Необхідно з'ясувати динаміку відхилень інших маркерів ушкодження в посттравматичному періоді для вироблення єдиної схеми патогенезу розробленої моделі краніоскелетної травми та механізмів корегувальної дії клітинної терапії. 
Огляди літератури, оригінальні дослідження, погляд на проблему

\section{ЛІТЕРАТУРА}

1. Борис Р. М. Вплив трансплантації ембріональних прогеніторних клітин на функціональний стан нирок у щурів з колоногенним перитонітом / Р. М. Борис, О. Л. Кухарчук // Експериментальна і клінічна медицина. - 2010. - № 3 (48). - С. 25-31.

2. Борис Р. М. Динаміка показників пероксидного окиснення ліпідів у період ранніх і пізніх проявів травматичної хвороби за умов експериментальної краніоскелетної травми та їі корекції клітинною терапією / Р. М. Борис, А. І. Гоженко, А. А. Гудима // Клінічна та експериментальна патологія. - 2013. - Т. XII, № 2 (44). - С. 31-34.

3. Борис Р. М. Динаміка показників ферментативної ланки антиоксидантного захисту в період ранніх та пізніх проявів травматичної хвороби в умовах експериментальної краніоскелетної травми та її корекції клітинною терапією / Р. М. Борис, А. М. Гольцев, А. І. Гоженко // Архив клинической и экспериментальной медицины. - 2013. - Т. 22, № 1. - С. 23-28.

4. Апоптические процессы в тимусе и головном мозгепри развитииэкспериментального аллергического энцефаломиелита до и после лечения фетальными нервными клетками / А. Н. Гольцев, Е. А. Порожан, Н. Н. Бабенко, М. В. Останков // Патология. - 2001. - Т. 8, № 2. - C. 69-72.

5. Фетальная, клеточная и тканевая терапия: результаты и перспективы применения в акушерстве и гинекологии /В.И. Грищенко, Н. А. Щербина, О. П. Танько [и др.] // Акушерство и гинекология. - 2001. - № 2. - С. 6-8.
6. Дзюба Д. А. Показатели активации апоптоза в течении политравмы тяжелой степени / Д. А. Дзюба, И. Р. Малыш, Л. В Згржебловская // Український журнал екстремальної медицини імені Г. О. Можаєва. - 2008. Т. 9, № 1. - С. 53-58.

7. Ельский В.Н. Моделирование черепно-мозговой травмы / В. Н. Ельский, С. В. Зяблицев. - Донецк : Издво “Новый мир”, 2008. - 140 с.

8. Козак Д. В. Динаміка показників цитолізу в умовах політравми / Д. В. Козак // Шпитальна хірургія. 2012. - № 2. - С. 50-52.

9. Терапия фетальными нервными клетками в остром периоде экспериментального ишемического инсульта (антиоксидантный эффект) / Д. В. Лебединец, С. Е. Овсянников, В. В. Лебединец [и др.] // Проблемы криобиологии. - 2010. - Т. 20, № 3. - С. 338-347.

10. Надання медичної допомоги постраждалим 3 політравмою на догоспітальному етапі : методичні рекомендації / Г. Г. Рощін, Ю. О. ГайдаєВ, О.В.Мазуренко [та ін.]. - К., 2003. - 33 С.

11. Сергиенко Н. М. Трансплантация эмбриональной сетчатки в субретинальное пространство / Н. М. Сергиенко, Н. В. Пасечникова, Д. В. Варивончик // Офтальмол. журнал. - 1998. - № 3. - С. 241-246.

12. Влияние фетальных нервных клеток на восстановление подвижности конечностей крыс с травматическим повреждением спинного мозга / А. Н. Сукач, А. С. Лебединский, О. В. Оченашко, А. Ю. Петренко // Медицина сьогодні і завтра. - 2011. - № 1-2. - С. 50-51.

\section{EFFECT OF CELL THERAPY FOR DYNAMIC PROCESS CYTOLISIS IN EARLY AND LATE PERIOD OF COMBINED CRANIOSKELETAL INJURY COMPLICATED BY BLOOD LOSS}

OR. M. Borys

\section{PHEI «Kyiv Medical University UANM» of MPH of Ukraine}

SUMMARY. In terms of cranioskeletal injury complicated by blood loss during the period of early and late manifestations of traumatic disease (3-25 days) there was marked a pronounced cytolysis syndrome, which is accompanied by a significant increase in activity aspartate - alanine aminotransferase and serum for 25 days post-traumatic period. The use of cryopreserved fetal nerve cells in these experimental conditions, accompanied by a pronounced cytoprotective effect is most pronounced at 14 and 25 days of experiment.

KEY WORDS: cranioskeletal injury, blood loss, cell therapy, cytolysis. 